\title{
PCBs and PAHs in sea-surface microlayer and sub-surface water samples of the Venice Lagoon (Italy)
}

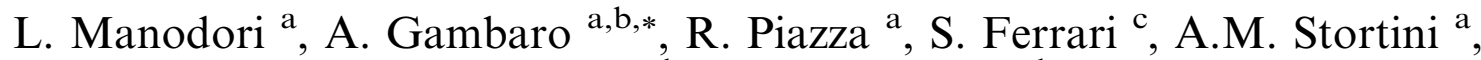 \\ I. Moret ${ }^{\mathrm{a}, \mathrm{b}}$, G. Capodaglio ${ }^{\mathrm{a}, \mathrm{b}}$ \\ a Environmental Sciences Department, Ca' Foscari University of Venice, 30123 Venice, Italy \\ ${ }^{\mathrm{b}}$ Institute for the Dynamics of Environmental Processes, C.N.R., 30123 Venice, Italy \\ ${ }^{\mathrm{c}}$ Institute of Atmospheric Sciences and Climate, C.N.R., 40129 Bologna, Italy
}

\begin{abstract}
Polychlorinated biphenyls (PCBs) and polycyclic aromatic hydrocarbons (PAHs) are two classes of micropollutants intensively monitored and regulated due to their toxicity, persistency and wide diffusion. Their concentrations have been investigated in sea-microlayer (SML) and sub-surface water (SSW) samples collected at two sites of the Venice Lagoon, a fragile ecosystem highly influenced by industrial and anthropogenic emissions. The total $\sum$ PCB concentration varies from $0.45 \mathrm{ng} / 1$ to $2.1 \mathrm{ng} / 1 \mathrm{in} \mathrm{SSW}$ while a clear enrichment is observed in the SML, where it ranges from $1.2 \mathrm{ng} / 1$ to $10.5 \mathrm{ng} / 1$. The total $\sum \mathrm{PAH}$ concentration shows marked differences between the two stations and varies from $12.4 \mathrm{ng} / 1$ to $266.8 \mathrm{ng} / 1$ in SSW; in SML it is more uniform and ranges from $19.6 \mathrm{ng} / 1$ to $178.9 \mathrm{ng} / 1$. The enrichment factors are not larger than 1 for both pollutants in the 'dissolved' phase, while they are most significant for the 'particulate'

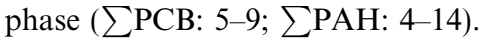

(C) 2005 Elsevier Ltd. All rights reserved.

Keywords: GC-MS; Sea-surface microlayer; PAHs; PCBs; Pollution; Sub-surface water; Venice Lagoon

\section{Introduction}

The air-water interface plays a key role in the exchange and distribution of persistent organic pollutants (POPs) and has to be taken into account when their environmental fate and budget calculations are investigated (Wania et al., 1998). In the first $50 \mu \mathrm{m}$ over 20 properties such as the concentration of suspended particles, density, $\mathrm{pH}$ value, complexing capacity and so on change sharply (Zhang et al., 2003a); these unique characteristics contribute to an increase in the interfacial effect of the sea microlayer, which features a unique chemical composition (high content of lipids, fatty acids and protein) that leads to its

\footnotetext{
* Corresponding author. Address: Environmental Sciences Department, Ca' Foscari University of Venice, 30123 Venice, Italy. Tel.: +39 41 2348950; fax: +39 412348549 .

E-mail address: gambaro@unive.it (A. Gambaro).
}

capacity for accumulating hydrophobic organic pollutants, which may be transferred to the air via volatilisation or bubble bursting.

This paper focuses on an assessment of the sea-surface microlayer and sub-surface water concentrations of two classes of POPs: polychlorinated biphenyls (PCBs) and polycyclic aromatic hydrocarbons (PAHs) which in recent decades have attracted the attention of scientific and policy maker communities (Jones and de Voogt, 1999; Lerche et al., 2002; Eljarrat and Barceló, 2003) due to their persistence, their capacity to bioaccumulate in the food chain and their toxic properties. The investigated area is the Venice Lagoon, a shallow and fragile transitional ecosystem which is strongly influenced by human presence and subject to special laws to preserve and improve its environmental quality. To our knowledge, the first study about contamination of the sea-surface microlayer of the Venice lagoon was done by Cleary et al. (2000) who collected water samples in the lagoon and in the Adriatic Sea on May 
1993. They found a clear enrichment of metals and organic pollutants (organotins and polyaromatic hydrocarbons) in the lagoon waters with respect to the Adriatic, particularly near the industrial plants of Porto Marghera. Moreover they supposed that tidal currents coupled with the busy traffic and shallow waters can strongly influence its chemical composition, due to resuspension of particulate matter.

The main aims of this study are to provide updated data about PCB and PAH concentrations in sea-surface microlayer and sub-surface waters to complete the picture of the environmental pollution of the Venice Lagoon and to evaluate the role of this thin air-water interface in the dispersion of POPs in a transitional environment by analyzing the sea-surface microlayer composition in relation to the potential sources of these pollutants.

\section{Experimental methods}

\subsection{Sampling}

Sea-surface microlayer (SML) and sub-surface (SSW) water samples were collected between July 2001 and June 2003 at two different sites in the Venice Lagoon, as de-

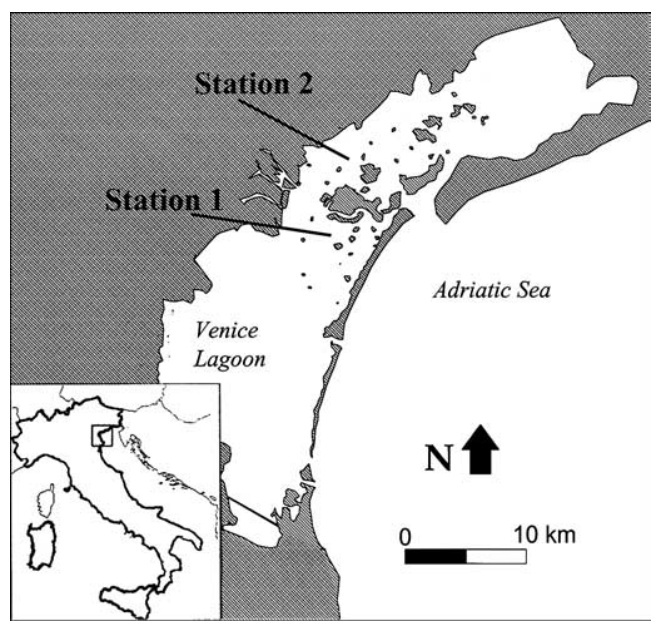

Fig. 1. Map of sampling stations. picted in Fig. 1. Both of them are characterized by shallow waters whose chemical composition may be influenced by processes that perturb the physical and chemical partitioning of pollutants, such as the enhanced resuspension from sediments or the prevention of fine-size particle settling. All these processes have to be taken into account because they are important in the lagoon, in which average water depth is about $0.6 \mathrm{~m}$ and the tidal excursion is lower than $1 \mathrm{~m}$ (Cochran et al., 1998).

Station 1 was located in the central part of the lagoon near the island of Sacca Sessola, about $3 \mathrm{~km}$ to the south of the city of Venice and $7 \mathrm{~km}$ east of the industrial plants of Porto Marghera. This area is shallow (about $0.60 \mathrm{~m}$ ) and is surrounded by a net of navigable canals directly connected with the Lido inlet which are not intensively travelled. Station 2 was about $3 \mathrm{~km}$ north of the Venice urban area, in the zone between the islands of Tessera, Campalto and Murano. It is deeper (about $1 \mathrm{~m}$ ) than Station 1 and is crossed on one side by the intensively used Tessera canal (average depth $2.5 \mathrm{~m}$ ), which connects the international 'Marco Polo' airport to the city of Venice.

Five sampling campaigns were performed at each station, on neap tide days and under calm water conditions; Table 1 reports general information about the sampling campaigns, including the collection dates and the main meteorological parameter averages over the sampling time.

SML and SSW samples were simultaneously collected by the Multi-Use Microlayer Sampler (MUMS; Cincinelli et al., 2001), an autonomous floating device which is electrically powered and radio-controlled. The MUMS collected the sea-surface microlayer water (mean thickness: $<50 \mu \mathrm{m}$; covered area: about $100 \mathrm{~m}^{2}$ ) by means of a rotating Pyrex glass drum and a Mylar scraper removed it from the glass surface. SML samples were collected by a Teflon membrane pump in a carefully cleaned aluminium bottle and at same time another pump collected SSW samples $(0.30 \mathrm{~m}$ deep $)$ in another aluminium bottle.

The use of a rotating drum was recommended by Cleary et al. (2000) to improve their initial study about the Venice Lagoon microlayer and recently, Zhang et al. (2003a) and Wurl and Obbard (2004) have suggested that it is the better sea-surface microlayer sampling device because it collects a

Table 1

Summary of the performed sampling campaigns (n. a. means 'not available')

\begin{tabular}{|c|c|c|c|c|c|c|c|}
\hline Sampling site & Date of sampling & Temperature, ${ }^{\circ} \mathrm{C}$ & $\begin{array}{l}\text { Relative } \\
\text { humidity, \% }\end{array}$ & $\begin{array}{l}\text { Atmospheric } \\
\text { pressure, } \mathrm{hPa}\end{array}$ & $\begin{array}{l}\text { Wind } \\
\text { direction }\end{array}$ & $\begin{array}{l}\text { Wind } \\
\text { speed, } \mathrm{m} / \mathrm{s}\end{array}$ & $\begin{array}{l}\text { Sun irradiation, } \\
\mathrm{kJ} / \mathrm{m}^{2} / \mathrm{h}\end{array}$ \\
\hline Station 1 & $18 / 07 / 2001$ & 24.2 & n.a. & 1006.7 & n.a. & 4.6 & 1954 \\
\hline Station 2 & $27 / 07 / 2001$ & 27.7 & n.a. & 1014.5 & ES & 2.4 & 2322 \\
\hline Station 1 & $21 / 03 / 2002$ & 14.0 & 88.3 & 1011.0 & $\mathrm{~S}$ & 2.7 & 1849 \\
\hline Station 2 & $18 / 04 / 2002$ & 14.9 & 57.2 & 1010.5 & ES & 2.2 & 1800 \\
\hline Station 1 & $15 / 10 / 2002$ & 17.4 & 81.2 & 1012.9 & NE & 1.4 & 923 \\
\hline Station 2 & $16 / 12 / 2002$ & 5.7 & 97.9 & 1015.8 & SW & 2.2 & 380 \\
\hline Station 2 & $12 / 03 / 2003^{\mathrm{a}}$ & 9.0 & 99.0 & 1013.6 & SW & 1.0 & 453 \\
\hline Station 1 & $26 / 03 / 2003$ & 13.8 & 41.7 & 1013.8 & ES & 2.0 & 1951 \\
\hline Station 1 & $05 / 06 / 2003$ & 25.3 & 59.0 & 1017.4 & ES & 4.2 & 2613 \\
\hline Station 2 & $19 / 06 / 2003$ & 25.3 & 58.7 & 1015.8 & ES & 4.1 & 2669 \\
\hline
\end{tabular}

\footnotetext{
${ }^{a}$ Due to irreparable breakage of the extraction apparatus, the 'dissolved' SSW and SML samples collected on 12/03/02 have been lost.
} 
suitable thickness layer and minimizes the risk of sample contamination by permitting the collection of several litres in a short time.

\subsection{Sample treatment}

The sample treatment and the analytical method applied have previously been described (Moret et al., 2005). Briefly, on return to the laboratory 101 of the SML and SSW samples were filtered by a stainless steel apparatus under vacuum conditions using glass-fibre filters $(G F / F$, porosity $\cong$ $0.7 \mu \mathrm{m}$ ) to separate particles (operationally defined) from the dissolved phase. Within $12 \mathrm{~h}$ the filtrate samples were liquid-liquid extracted for $24 \mathrm{~h}$ using $200 \mathrm{ml}$ of $n$-pentane and dichloromethane mixture (2:1 on volume basis) whilst particulate matter collected on filters was kept at $-20{ }^{\circ} \mathrm{C}$ until extraction. The 'particulate-bound' $\mathrm{PCB}$ and $\mathrm{PAH}$ were extracted by ultrasonic bath for $2 \mathrm{~h}$ using $60 \mathrm{ml}$ of the same kind of mixture. All the extracts were dried by adding anhydrous sodium sulphate then the volume was reduced to $2 \mathrm{ml}$ under gentle nitrogen flow. Sample clean up was performed by a chromatography column made up by alumina $(1 \mathrm{~cm})$ on the bottom and florisil $(2 \mathrm{~cm})$ on top and eluted with $30 \mathrm{ml}$ of $n$-hexane. Elutes were then reduced to $100 \mu \mathrm{l}$ with nitrogen flow and analyzed by HRGC-LRMS. For quantification purposes, known amounts of labelled ${ }^{13} \mathrm{C}$ PCB (completely ${ }^{13} \mathrm{C}$ labelled PCB 28, 52, 101, 138, 153, 180; Cambridge Isotope Laboratories, Andover, Massachusetts, USA) and labelled ${ }^{13} \mathrm{C}$ PAH (Phenanthrene ${ }^{13} \mathrm{C}_{6}$, Cambridge Isotope Laboratories, Andover, Massachusetts, USA) mixtures were added to samples before extraction.

\section{3. $G C-M S$ analysis}

All samples were analyzed with a Hewlett-Packard model 5890 series II gas chromatograph coupled with a HewlettPackard model 5970 Mass Selective Detector, equipped with a fused silica capillary column (Agilent Tecnology DB-5MS, $60 \mathrm{~m} \times 0.250 \mathrm{~mm} \times 0.25 \mu \mathrm{m})$. Data were acquired in the electron impact (EI) mode $(70 \mathrm{eV})$ using the selected ion monitoring (SIM) technique. 54 PCBs $(18,17,28+31,20+33$, $52,49,44,41+64,74,70,66,95,91,60+56,92$, $84+90+101,99,97,87+115,85,136,110,151,135$, $149,118,146,153,132,105,141,179,137,176,138,158$, $187,183,128+167,156,180,170+190,203+196,194)$ and 20 PAHs (Acenaphthylene $=$ Acy; Acenaphthene = Ace; Fluorene $=$ Flu; Dibenzothiophene $=$ Dbt; Phenanthrene $=$ Phe; $\quad$ Anthracene $=$ An; 2-methylphenanthrene = 2-Me; $4 \mathrm{H}$-cyclopenta $(d, e, f)$ phenanthrene $=4 \mathrm{H}$-Cphe; 1 -methylphenanthrene $=1-\mathrm{Me} ;$ Fluoranthene $=$ Flt; Pyrene $=$ Py; Benzo $(g, h, i)$ fluoranthene $+\operatorname{Benzo}(c)$ phenanthrene $=$ Bphe; Benzo (a) anthracene $=$ Ban; Chrysene + Triphenylene $=$ Cry + Try; $\operatorname{Benzo}(b)$ fluoranthene $+\operatorname{Benzo}(j)$ fluoranthene $+\operatorname{Benzo}(k)$ fluoranthene $=\mathrm{Bflt}$; $\operatorname{Benzo}(a)$ pyrene $=\mathrm{Bpy}$,$) correspond-$ ing to 44 and 16 chromatographic peaks, respectively, were determined by applying the isotopic dilution method.
Results were corrected by a response factor calculated for every compound and periodically evaluated.

\subsection{Quality control}

To estimate the repeatability and accuracy of the analytical method every sample was spiked with known amounts of surrogate standard mixtures before extraction. Fifty pg/1 of a mixture consisting of unlabelled PCB\#30, PCB\#65, PCB\#96, PCB\#166, PCB\#189 and PCB\#199 and $0.5 \mathrm{ng} / 1$ of fluorene- $d_{10}$ was added.

The relative errors for the majority of spiked PCBs ranged from $-15.2 \%$ to $16.5 \%$ and the relative standard deviations vary from $6.8 \%$ to $29.1 \%$. The highest errors $(17.1 \%$ and $30.8 \%$ ) and the worst relative standard deviation values $(33.5 \%$ and $45.8 \%)$ were found for PCB\#189 in 'particulate' samples both of SSW and SML and they were probably due to the presence of interferences (Sauer et al., 1989). The relative error of fluorene- $d_{10}$ ranged from $-11.8 \%$ to $9.4 \%$ and its repeatability from $26.0 \%$ to $45.6 \%$ with uncertainty rising with the increase of matrix complexity.

The average recovery for $\sum \mathrm{PCB}$ and $\sum \mathrm{PAH}$ in both 'dissolved' and 'particulate' phases are greater than $85 \%$ and $80 \%$, respectively.

Intensive efforts were made to avoid sample contamination. To evaluate procedural and laboratory contamination several working blanks consisting of tap water and new filters were run as samples. In water blanks only PCB\#18, $84+90+101$ and 149 were found and the sum of their concentration was about $7 \mathrm{pg} / \mathrm{l}$; in the particulate blanks the same total concentration was found, and it consisted of PCB\#52, 84 +90+101 and 118. The concentration of detected PAHs (Acy, Ace, Flu and Phe) in water blanks was about $0.4 \mathrm{ng} / 1$ while in particulate blanks it was about $0.6 \mathrm{ng} / \mathrm{l}$, containing a larger number of compounds (the ones listed above plus Flt, Py, 1-Me and 2-Me). These values show that the contamination from the entire analytical procedure can be neglected both in 'dissolved' and 'particulate' SSW and SML samples, so results were not corrected for the blank.

\section{Results and discussion}

\subsection{Sub-surface water}

Median, minimum and maximum concentrations of PCBs and PAHs in the 'dissolved' and 'particulate' phases of sub-surface water at stations 1 and 2 are listed in Table 2.

The total (sum of 'dissolved' and 'particulate') concentration of $\sum$ PCBs in sub-surface water at station 1 varies from $0.45 \mathrm{ng} / 1$ to $1.5 \mathrm{ng} / 1$ and the median value is $0.8 \mathrm{ng} /$ 1. The majority of samples show a preferential accumulation in the 'dissolved' phase with respect to the 'particulate' one, as can also be observed by comparing the median 'dissolved' particulate' concentration $(0.53 \mathrm{ng} / 1$ and $0.24 \mathrm{ng} / \mathrm{l}$, 
Table 2

Median (minimum-maximum) concentrations of selected PCBs (pg/l) and PAHs (ng/l) in SSW at both sampling sites

\begin{tabular}{|c|c|c|c|c|}
\hline & \multicolumn{2}{|l|}{ Station 1} & \multicolumn{2}{|l|}{ Station 2} \\
\hline & 'Dissolved' SSW & 'Particulate' SSW & 'Dissolved' SSW & 'Particulate' SSW \\
\hline 18 & $19(13-29)$ & $3(2-30)$ & $16(10-34)$ & $5(2-31)$ \\
\hline $28+31$ & $28(21-40)$ & $9(8-30)$ & $23(10-48)$ & $15(10-100)$ \\
\hline 52 & $25(20-53)$ & $8(6-23)$ & $33(17-63)$ & $19(7-22)$ \\
\hline 95 & $21(13-30)$ & $9(6-28)$ & $25(14-33)$ & $19(7-28)$ \\
\hline $84+90+101$ & $57(22-385)$ & $22(17-94)$ & $44(21-82)$ & $62(18-80)$ \\
\hline 110 & $20(15-37)$ & $15(10-41)$ & $20(10-38)$ & $31(12-48)$ \\
\hline 153 & $25(13-38)$ & $21(15-58)$ & $27(12-42)$ & $38(18-117)$ \\
\hline 138 & $35(13-38)$ & $16(15-60)$ & $22\left(\begin{array}{ll}1 & 2-40\end{array}\right)$ & $34(20-103)$ \\
\hline 180 & $10(3-18)$ & $7(6-22)$ & $11(5-17)$ & $14(8-36)$ \\
\hline 194 & n.d. $(-)$ & n.d. (-) & n.d. $(-)$ & $2(2-13)$ \\
\hline$\sum \mathrm{PCB}$ & $529(261-871)$ & $239(192-769)$ & $463(233-899)$ & $503(226-1215)$ \\
\hline Acy & $0.24(0.13-0.43)$ & $0.13(0.11-0.20)$ & $0.61(0.23-164.31)$ & $0.45(0.10-0.42)$ \\
\hline Ace & $1.10(0.43-2.01)$ & $0.55(0.16-1.22)$ & $1.45(1.24-58.81)$ & $1.46(0.17-0.58)$ \\
\hline Flu & $1.01(0.38-1.66)$ & $0.20(0.17-0.46)$ & $1.41(0.99-8.72)$ & $1.38(0.30-0.90)$ \\
\hline Dbt & $0.16(0.09-0.21)$ & $0.09(0.04-0.11)$ & $0.21(0.16-1.11)$ & $0.25(0.09-0.34)$ \\
\hline Phe & $1.75(0.55-2.94)$ & $0.86(0.57-0.90)$ & $2.12(1.50-13.10)$ & $2.24(0.85-3.20)$ \\
\hline An & $0.12(0.04-0.22)$ & $0.12(0.10-0.15)$ & $0.26(0.06-1.36)$ & $0.21(0.14-0.87)$ \\
\hline 2-Me & $0.39(0.22-0.49)$ & $0.23(0.11-0.26)$ & $0.46(0.41-0.74)$ & $1.10(0.26-0.77)$ \\
\hline 4H-Cphe & $0.34(0.25-0.54)$ & $0.14(0.09-0.15)$ & $0.31(0.27-1.84)$ & 0.61 (n.d. -0.67 ) \\
\hline $1-\mathrm{Me}^{\mathrm{T}}$ & $0.28(0.17-1.20)$ & $0.07(0.02-0.17)$ & $0.37(0.27-15.37)$ & $0.45(0.14-0.73)$ \\
\hline Flt & $1.15(0.56-1.87)$ & $1.14(0.81-1.28)$ & $1.17(0.60-1.84)$ & $2.69(1.30-6.32)$ \\
\hline Py & $1.31(0.81-2.47)$ & $1.05(0.97-1.19)$ & $1.31(1.02-2.88)$ & 2.51 (n.d. -5.85$)$ \\
\hline Bphe & $0.14(0.06-0.21)$ & $0.32(0.13-0.46)$ & 0.03 (n.d. -0.30 ) & $0.34(0.20-1.50)$ \\
\hline Ban & 0.06 (n.d. -0.12 ) & $0.56(0.37-1.51)$ & 0.05 (n.d. -0.11 ) & $0.06(0.51-3.72)$ \\
\hline Cry + Try & 0.14 (n.d. -0.30 ) & $0.54(0.35-0.67)$ & 0.04 (n.d. -0.76 ) & $0.12(0.60-3.53)$ \\
\hline Bflt & 0.04 (n.d. -0.22 ) & $1.49(0.84-1.55)$ & 0.07 (n.d. -0.37 ) & 0.06 (n.d.-8.64) \\
\hline Bpy & n.d. (n.d.-0.05) & 0.71 (n.d. -0.93 ) & n.d. (n.d. -0.03 ) & n.d. (n.d.-7.14) \\
\hline$\sum \mathrm{PAH}$ & $8.77(6.31-11.28)$ & $866(5.68-9.22)$ & $11.62(7.96-258.85)$ & $15.96(7.95-45.15)$ \\
\hline
\end{tabular}

n.d. $=$ Not detectable.

respectively). Penta-chlorobiphenyls are the most abundant homolog and very high concentrations were found for PCBs $84+90+101(18.6 \%), 153,(5.9 \%)$ and $138(5.3 \%)$.

The PCBs distribution is different between the two phases, as can be observed in Fig. 2a. The most chlorinated biphenyls (hexa- plus hepta and octa-CBs) constitute a higher percentage of the total concentration in the "particulate' phase than in the 'dissolved' phase.

At station 2 the total (sum of 'dissolved' and 'particulate') median concentration of $\sum$ PCBs is similar to the value found at station $1(1.0 \mathrm{ng} / \mathrm{l})$ while the range of variation is wider $(0.5-2.1 \mathrm{ng} / \mathrm{l})$. Except for the SSW sample collected on 16 December 2002, in which 'dissolved' and 'particulate' concentrations are very low and similar $(0.27 \mathrm{ng} / 1$ and $0.23 \mathrm{ng} / \mathrm{l}$, respectively), it can be observed that PCBs are preferentially accumulated in the 'particulate' phase (range 0.34-1.2 ng/l) rather than in the 'dissolved' form (range $0.23-0.90 \mathrm{ng} / \mathrm{l}$ ). Hexa- and penta-CBs constitute about $62 \%$ of the total concentration to which PCBs $84+90+$ 101,153 and 138 mainly contribute.

As previously observed for station 1 , the congener distribution reflects the different affinities for particulate matter with the lightest homologs preferentially present in the "dissolved' phase (Fig. 2a).

The PCB concentrations found in this work are at ppq (parts per quadrillion) levels and are comparable with re- sults previously obtained for the Venice Lagoon by Moret et al. (2005); however they are some orders of magnitude lower than the values reported by García-Flor et al. (2005) for Spanish and French coastal waters and by Zhang et al. (2003b) for Chinese estuary waters.

Concerning PAH, at station 1 the total (sum of 'dissolved' and 'particulate') $\sum$ PAH concentration ranges from $12.4 \mathrm{ng} / 1$ to $20.5 \mathrm{ng} / 1$ and the median value is $17.3 \mathrm{ng} / \mathrm{l}$; the most abundant compounds are Py, Phe and Flt, which represent $13 \%-16 \%$ of the total concentration.

$\sum$ PAHs concentration are slightly higher in the 'dissolved' (6.76-11.3 ng/l) than in 'particulate' phases (5.68$9.22 \mathrm{ng} / \mathrm{l})$ and only the SSW sample collected on 18 July 2001 shows an opposite preferential accumulation in the particulate matter. At station 2 the average total (sum of 'dissolved' and 'particulate') concentration of $\sum$ PAHs in SSW is about 3 times larger than at station 1 ranging from $21.3 \mathrm{ng} / 1$ to $266.8 \mathrm{ng} / 1$ (median concentration: $56.8 \mathrm{ng} / \mathrm{l}$ ) and Acy and Ace are the most abundant species. Generally the distribution between the 'particulate' and 'dissolved' phases is strictly related to the $K_{\mathrm{ow}}$ of the compounds as observed in Fig. 2a; while three-ring PAHs are predominant in the 'dissolved' phase, the heaviest PAHs are most abundant in the 'particulate' phase.

The $\sum \mathrm{PAH}$ concentrations found in this study rarely exceed $0.2 \mu \mathrm{g} / 1$ and are comparable with values found in 
(a)

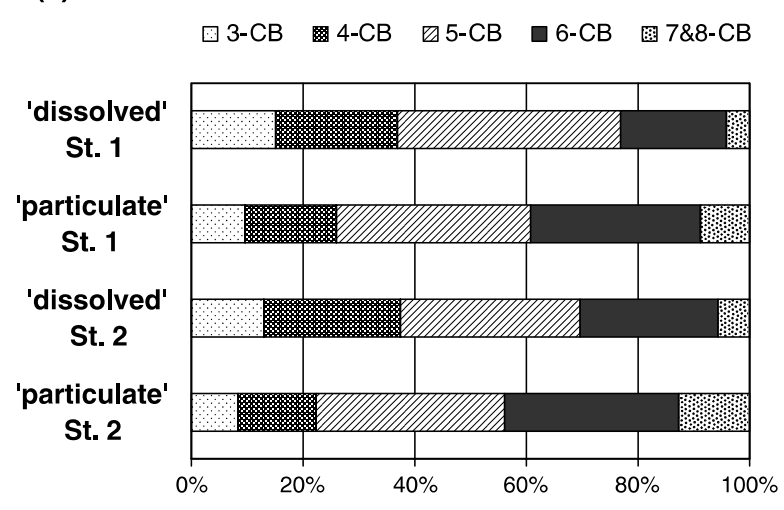

SSW

四3-rings $\mathrm{PAH}$ 圆 4-rings $\mathrm{PAH}$

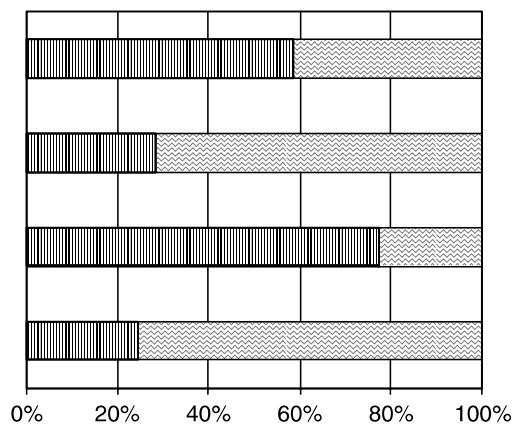

(b)

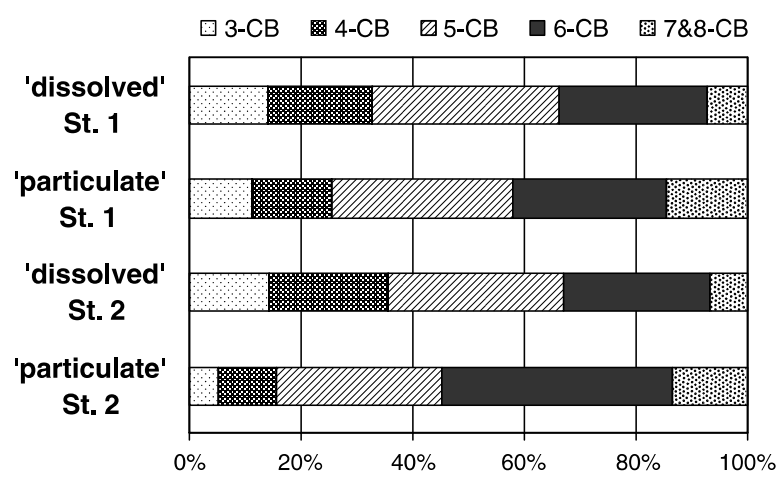

SML

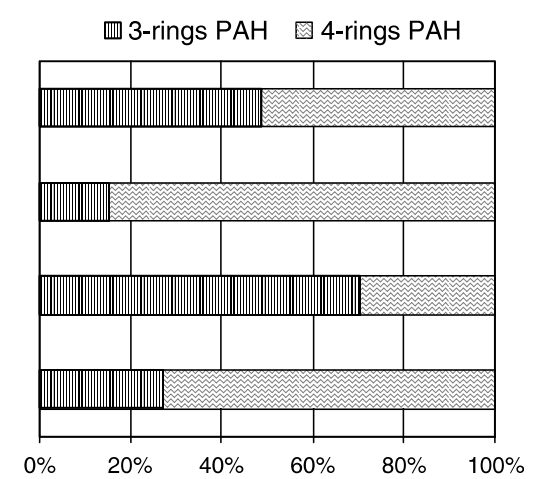

Fig. 2. Relative \% abundances of PCB homologs and PAH in the 'dissolved' and 'particulate' phases of SSW (a) and SML (b) at both stations.

other coastal areas (El Nemr and Abd-Allah, 2003; Kucklick and Bidleman, 1994) but about two orders of magnitude lower than those found in polluted environments (Anyakora et al., 2005; Cincinelli et al., 2001; Liu and Dickhut, 1997).

\subsection{Sea-surface microlayer waters}

Median, minimum and maximum concentrations of PCBs and PAHs in the 'dissolved' and 'particulate' phases of sea-surface microlayer water at stations 1 and 2 are reported in Table 3.

At station 1 the total (sum of 'dissolved' and 'particulate') concentration of $\sum$ PCBs ranges from 1.2 to $4.0 \mathrm{ng} /$ 1 , and the median concentration is $2.1 \mathrm{ng} / \mathrm{l}$. Unlike SSW, a preferential accumulation in the 'particulate' phase exists for all samples: the median $\sum$ PCB concentration in the 'dissolved' SML is $0.5 \mathrm{ng} / 1$ (ranging between 0.34 and $1.1 \mathrm{ng} / \mathrm{l}$ ) and it is $1.1 \mathrm{ng} / \mathrm{l}$ in the 'particulate' (range between $0.9 \mathrm{ng} / 1$ and $3.5 \mathrm{ng} / \mathrm{l}$ ). The predominant homologs are hexa- and penta-CBs and the congeners with the highest concentration are PCB $84+90+101,153,138$ and 180 .

In both the 'dissolved' and 'particulate' phases the penta$\mathrm{CBs}$ are the predominant group (Fig. 2b) while the most chlorinated biphenyls (hexa- plus hepta and octa-CBs) constitute a higher percentage of the total concentration in the 'particulate' phase than in the 'dissolved' phase.
At station 2 the median total (sum of 'dissolved' and 'particulate') concentration of $\sum$ PCBs in SML is $3.3 \mathrm{ng} / 1$ and it ranges more widely than at Station 1 , from $0.7 \mathrm{ng} /$ 1 to $10.5 \mathrm{ng} / \mathrm{l}$. Hexa-chlorinated biphenyls are the most abundant and PCBs 153 and 138 constitute about $25 \%$ of the total concentration. Plainly PCBs are preferentially present in the 'particulate' form (range: $1.8-9.9 \mathrm{ng} / \mathrm{l}$ ) rather than in the 'dissolved' phase, where the range of variation of PCBs is quite similar to that observed at station 1 $(0.4-1.0 \mathrm{ng} / \mathrm{l})$ except in the SML sample collected on 19 June 2003, in which concentrations are very similar in both phases (about $0.3 \mathrm{ng} / \mathrm{l}$ ). The distribution of tri-plus tetraCBs and hexa- plus hepta and octa-CBs is similar to that found at station 1 (Fig. 2b), while in the particulate matter the most abundant homolog group is hexa-CBs, which together with epta and octa-CBs constitute up to $55 \%$ of total concentration.

As observed by Wurl and Obbard (2004) it is hard to compare the results from studies using different sampling devices because different layer thicknesses may have been collected; however it can be pointed out that PCB concentration in SML waters of the Venice Lagoon are comparable with those obtained by García-Flor et al. (2005) at Barcelona but lower than values found by Abd-Allah (1999) for the Egyptian coast (36-412 ng/l) and by Picer and Picer (1992) for Rijeka Bay in Croatia (75.3 \pm $142 \mathrm{ng} / \mathrm{l})$. 
Table 3

Median (minimum-maximum) concentrations of selected PCBs (pg/l) and PAHs (ng/l) in SML at both sampling sites

\begin{tabular}{|c|c|c|c|c|}
\hline & \multicolumn{2}{|l|}{ Station 1} & \multicolumn{2}{|l|}{ Station 2} \\
\hline & 'Dissolved' SML & 'Particulate' SML & 'Dissolved' SML & 'Particulate' SML \\
\hline 18 & $15(14-48)$ & $29(7-130)$ & $17(11-35)$ & $20(3-58)$ \\
\hline $28+31$ & $26(23-47)$ & $25(23-60)$ & $35(18-50)$ & $27(13-155)$ \\
\hline 52 & $21(15-63)$ & $36(22-74)$ & $23(23-70)$ & $59(11-147)$ \\
\hline 95 & $24(15-32)$ & $56(24-76)$ & $25(20-39)$ & $74(12-255)$ \\
\hline $84+90+101$ & $51(29-146)$ & $149(59-165)$ & $39(32-119)$ & $169(34-672)$ \\
\hline 110 & $28(18-48)$ & $103(46-151)$ & $26(20-48)$ & $139(21-447)$ \\
\hline 153 & $34(17-55)$ & $113(44-264)$ & $38(19-51)$ & $217(25-1645)$ \\
\hline 138 & $39(16-56)$ & $127(42-318)$ & $30(18-57)$ & $280(23-1452)$ \\
\hline 180 & $17(7-27)$ & $73(55-216)$ & $11(9-23)$ & $122(10-440)$ \\
\hline 194 & n.d. $(-)$ & $19(14-25)$ & n.d. $(-)$ & $31(17-55)$ \\
\hline$\sum \mathrm{PCB}$ & $487(343-1084)$ & $1215(901-3498)$ & $477(370-1002)$ & $2578(346-9929)$ \\
\hline Acy & $0.32(0.17-0.56)$ & $0.63(0.40-1.50)$ & $0.45(0.18-41.80)$ & $0.48(0.14-1.06)$ \\
\hline Ace & $1.43(0.77-2.13)$ & $1.07(0.49-1.30)$ & $1.46(1.32-68.46)$ & $0.37(0.33-2.01)$ \\
\hline Flu & $1.15(0.62-2.01)$ & $1.18(0.74-1.55)$ & $1.38(1.05-8.29)$ & $1.00(0.52-2.00)$ \\
\hline Dbt & $0.31(0.13-0.34)$ & $0.84(0.34-1.25)$ & $0.25(0.17-0.90)$ & $0.31(0.23-0.74)$ \\
\hline Phe & $2.91(1.41-4.03)$ & $7.41(4.48-13.34)$ & $2.24(2.06-17.54)$ & $5.11(2.50-11.09)$ \\
\hline An & $0.28(0.12-0.42)$ & $1.99(1.00-3.28)$ & $0.21(0.06-2.12)$ & $0.69(0.14-2.27)$ \\
\hline 2-Me & $0.61(0.36-0.88)$ & $1.65(0.99-2.52)$ & $1.10(0.42-15.80)$ & $1.05(0.66-2.40)$ \\
\hline 4H-Cphe & $0.40(0.19-1.06)$ & $0.96(0.67-1.65)$ & $0.61(0.28-2.62)$ & $0.74(0.41-1.09)$ \\
\hline $1-\mathrm{Me}^{\mathrm{T}}$ & $0.28(0.21-0.52)$ & $0.80(0.35-1.46)$ & $0.45(0.38-1.39)$ & $0.81(0.47-1.42)$ \\
\hline Flt & $2.37(1.46-6.53)$ & $15.82(7.78-19.40)$ & $2.69(1.24-4.26)$ & 5.77 (n.d.-8.29) \\
\hline Py & $2.26(1.27-5.27)$ & $11.88(6.84-18.78)$ & $2.51(1.24-7.41)$ & $5.28(0.06-15.62)$ \\
\hline Bphe & $0.35(0.14-0.47)$ & $3.07(0.73-5.25)$ & $0.34(0.16-0.52)$ & $1.90(0.83-2.66)$ \\
\hline Ban & 0.11 (n.d. -0.70 ) & $10.43(4.14-14.35)$ & 0.06 (n.d. -0.37 ) & $2.21(0.07-15.70)$ \\
\hline Cry + Try & 0.37 (n.d. -1.27 ) & $9.94(3.55-13.80)$ & 0.12 (n.d. -0.28 ) & $2.51(2.21-11.78)$ \\
\hline Bflt & 0.17 (n.d. -0.57 ) & $24.13(11.89-51.48)$ & 0.06 (n.d. -0.36$)$ & 4.15 (n.d.-56.35) \\
\hline Bpy & n.d. (n.d.-0.04) & 14.95 (n.d. -32.53$)$ & n.d. (n.d. -0.03$)$ & 3.21 (n.d. -37.41$)$ \\
\hline$\sum \mathrm{PAH}$ & $15.73(8.32-20.52)$ & $121.46(59.39-158.09)$ & $15.96(10.06-138.27)$ & $30.60(30.31-162.93)$ \\
\hline
\end{tabular}

n.d. $=$ Not detectable.

The median $\sum \mathrm{PAH}$ concentration of total (sum of 'dissolved' and 'particulate') $\sum \mathrm{PAH}$ concentration at station 1 is $44.1 \mathrm{ng} / 1$ and ranges from $19.6 \mathrm{ng} / 1$ to $148 \mathrm{ng} / 1$ with Bphe, Flt and Py as major contributors. All SML samples show a preferential accumulation in the 'particulate' phase, in which median concentration $(121.5 \mathrm{ng} / \mathrm{l})$ is considerably higher than in the 'dissolved' phase $(15.7 \mathrm{ng} / \mathrm{l})$. In both phases the 4-ring PAHs are the most abundant compounds and Flt, Phe and Py predominate in the filtrates while Bphe and Bpy predominate in the particulate matter.

At station 2 the $\sum \mathrm{PAH}$ concentration in the total ('dissolved' plus 'particulate') sea-surface microlayer samples varies from $40.4 \mathrm{ng} / 1$ to $178.9 \mathrm{ng} / \mathrm{l}$ with the median value about three times higher $(126.9 \mathrm{ng} / \mathrm{l})$ than at station 1 . As previously observed for sub-surface water samples the most abundant compounds are Acy and Ace.

$\sum$ PAH concentration in the 'dissolved' samples varies from $10.1 \mathrm{ng} / 1$ to $138.3 \mathrm{ng} / 1$ and the largest fraction consists of three-ring PAHs (Fig. 2b), such as Acy and Ace; conversely in the 'particulate' phase PAH concentration ranges from $30.3 \mathrm{ng} / 1$ to $162.9 \mathrm{ng} / 1$ and four-ring PAHs are the most abundant, in particular Bphe and Bpy.

Literature data show PAH contamination increases in areas featuring anthropogenic coastal activities and in particular it has been observed that harbour size and the intensity of shipping traffic may influence PAH concentrations in SML (Wurl and Obbard, 2004). Despite the fact that important industrial and urban districts are located near the sampling sites, the PAH concentrations found in the sea-surface microlayer waters of the Venice Lagoon are lower than the values found in other coastal areas: at Livorno (Tyrrhenian Sea, Italy) Cincinelli et al. (2001) report total concentrations ranging from $1.8 \mu \mathrm{g} / 1$ to $157 \mu \mathrm{g} / \mathrm{l}$; on the Alexandria coast (Egypt) the mean concentration was $245 \mathrm{ng} / 1$ (El Nemr and Abd-Allah, 2003) while at Winyah Bay and North Inlet (South Carolina) it was $650 \pm$ 1200 ng/l (Kucklick and Bidleman, 1994). The PAH concentrations found in this study are also lower than those reported by Cleary et al. (2000) for sea-surface microlayer samples collected in 1993 close to the island of Venice, which ranged from $7.18 \mu \mathrm{g} / 1$ to $10.416 \mu \mathrm{g} / 1$.

\subsection{Sea-surface microlayer enrichment}

SML enrichment may be explained by considering the hydrophobic character of POPs and their great affinity with surfactants collected at the air-water interface (GarcíaFlor et al., 2005) and it may be well represented by the enrichment factor EF, calculated as the ratio between SML and SSW concentrations (Hardy et al., 1987). For $\sum$ PCBs in the 'dissolved' phase it varies from 0.7 to 1.5 at station 1 and from 0.8 to 2.0 at station 2 , while in the 'particulate' phase the enrichment is plainly evident and EF ranges from 2.0 to 10.1 at station 1 and from 0.7 to 
29.3 at station 2 . These values are slightly higher than those reported by García-Flor et al. (2005) who used a different sampling device (glass plate, metal screen and slick sampler). As depicted in Fig. 3a, at both sampling sites the EFs are larger for 'particulate' than for 'dissolved' phases and generally it increases with the degree of chlorination, as previously reported by other authors (García-Flor et al., 2005).

The PAH EF values in the 'dissolved' phase range from 1.3 to 2.2 at station 1 and from 0.4 to 2.0 at station 2 ; these values are low and do not show a significant enrichment (Fig. 3b). By contrast, an evident preferential accumulation in sea-surface microlayer waters is observed for the 'particulate' phase, despite the fact that EF values are lower than those reported by other authors (Cincinelli et al., 2001; Liu and Dickhut, 1997). It is useful to notice that at station 1 the highest EF for both 'dissolved' and 'particulate' phases are relative to samples collected when sun irradiation was lowest, probably related to the reduced photo-degradation that may occur in the sea-surface microlayer (Schroeder and Lane, 1988); however no particular seasonal trend can be deduced. The highest mean 'particulate' EF value detected at this site may be explained by supposing the presence of a local source, which may be constituted by
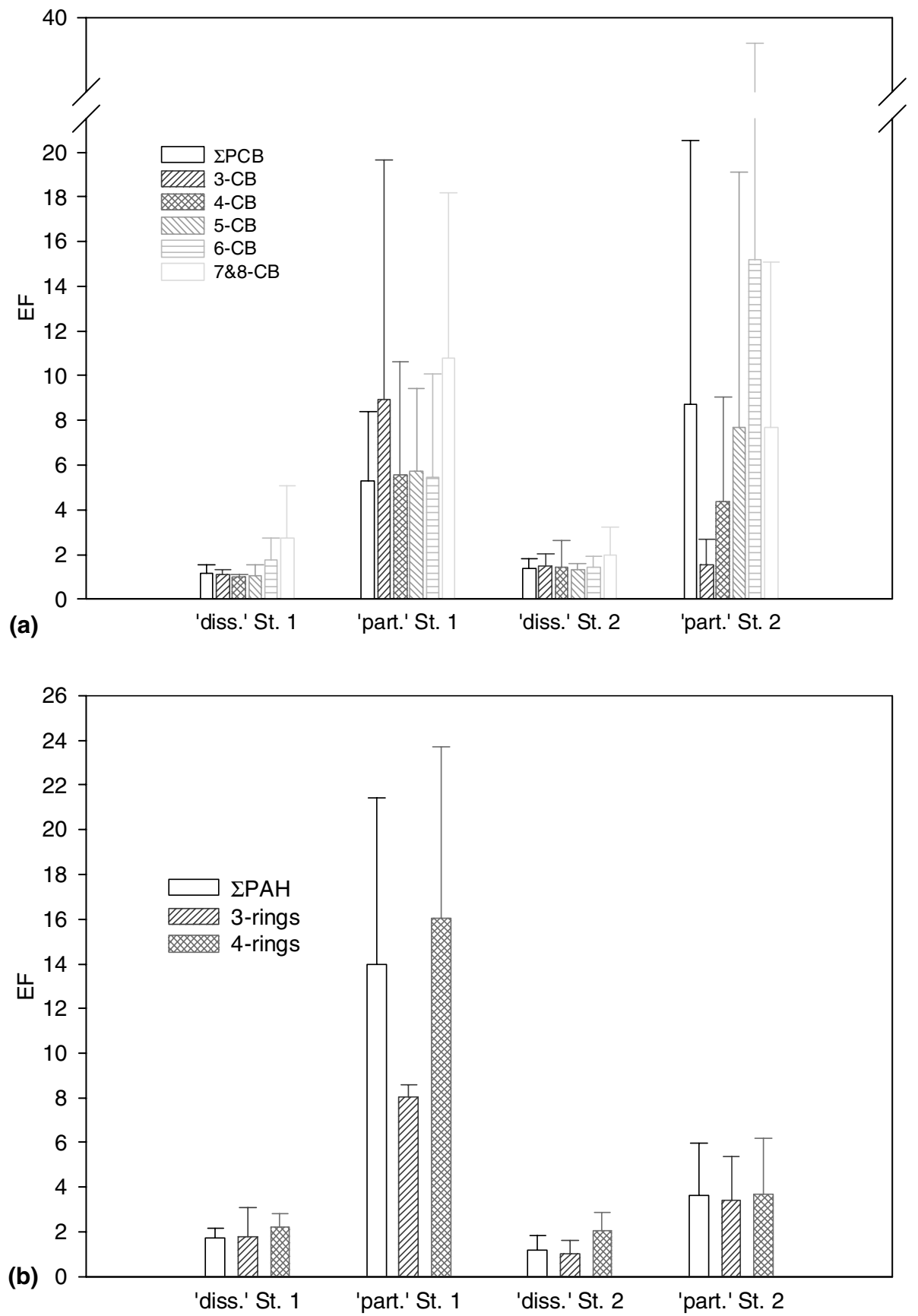

Fig. 3. Average 'dissolved' and 'particulate' enrichment factors (EF) for PCBs (a) and PAHs (b) at both sampling stations. 
emissions/fall outs from the nearby oil refineries of Porto Marghera.

\subsection{Pollutant sources}

Persistent organic pollutant concentrations in the water of a shallow semi-enclosed basin such as the Venice Lagoon are influenced by many factors, including direct discharges, the tide level, the presence of currents and sediment remobilization, etc. The sea-surface microlayer is not a final reservoir of pollutants but a dynamic compartment where POP concentration depends on the net balance of inputs (atmospheric depositions, sediment re-suspension, direct riverine contributions) and losses (volatilisation, bubble bursting, photo-decomposition, particle settlement) so it is hard to find a direct relationship between the different potential sources and the final concentration at the interface. The relationship between PCBs and PAHs and the main meteorological parameters (temperature, wind speed, solar irradiation) have been investigated, but no statistically significant results have been found, probably due to the concurrence of many factors or the spread of samples.

In previous studies many hypotheses were proposed to explain and evaluate the contribution of PAH contamination to the Venice Lagoon ecosystem and there was evidence to support the contention that the main contributions come from atmospheric depositions of combustion products (Secco et al., 2005; Wetzel and Van Vleet, 2003). A useful tool to evaluate their source is given by some PAH ratios. Budzinski et al. (1997) joined the information provided by two PAH ratios by plotting Phe/An against Flu/Py and suggested that PAH contamination of a pyrolytic origin is characterized by $\mathrm{Phe} / \mathrm{An}<10$ and $\mathrm{Flu} / \mathrm{Py}>1$ whilst contamination from petrogenic sources is characterized by Phe/An $>10$ and Flu/Py $<1$, as successively confirmed by other authors (El Nemr and AbdAllah, 2003). This approach was applied to dissolved and particulate samples of SML and SSW collected at stations 1 and 2, as plotted in Fig. 4. It can be observed that the majority of particulate samples (both SSW and SML) fall into the pyrolytic zone, whilst the dissolved ones are more diffuse and therefore a source cannot be assigned. Moreover at station 1 there is a very good correlation between Phe/An $(r=0.97)$ and Flu/Py $(r=0.96)$ using all samples but at station 2 it is very low (in both cases $r$ is less than 0.45 ) so it can be supposed that there must be many perturbing factors, such as miscellaneous sources and processes, as well as fresh oil spillage from motorized boats and the occurrence of selective photo-degradation or biodegradation affecting the different PAH (Tam et al., 2001).

Regarding PCBs, it is evident that their environmental concentrations have substantially declined in recent decades both in the western Mediterranean (Tolosa et al., 1997 ) and in the Venice lagoon sediments (Secco et al., 2005), because of their production has been banned, depuration systems have improved and natural degradation could have occurred. Di Domenico et al. (1996) reported
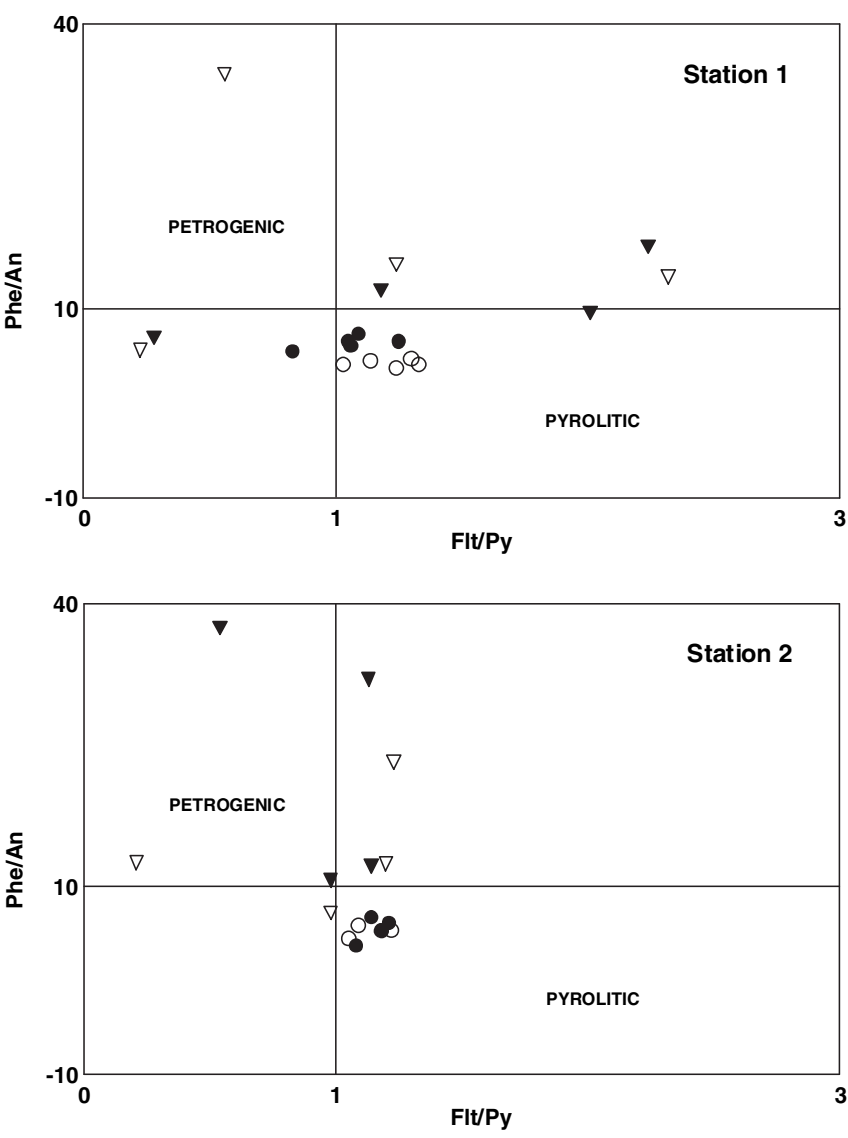

Fig. 4. Cross plots of the Phe/An versus Flt/Py values for all matrices at both sampling sites $((\nabla)$ dissolved SSW; $(\nabla)$ dissolved SML; particulate SSW; $(O)$ particulate SML).

that PCB contamination of the Venice Lagoon sediments derives mainly from anthropic impact without distinction between industrial and urban activities. By comparing the results obtained in this study with those reported for sediments by Secco et al. (2005) it can be observed that the PCB pattern in the 'particulate' SSW at both stations is similar to sediment composition, while the 'dissolved' SSW-SML and 'particulate' SML are mainly characterized by the least and the most hydrophobic congeners respectively. It can be hypothesized therefore that water contamination by $\mathrm{PCBs}$ derives from sediment re-suspension due to the shallow waters. This is followed by strong congener partitioning between the phases in accordance with their physical-chemical properties, which leads to microlayer enrichment by the most chlorinated biphenyls due to their highly hydrophobic behaviour.

\section{Conclusions}

Ten sampling campaigns have been performed to collect sub-surface and sea-surface microlayer water samples in two areas of the Venice Lagoon. The $\sum$ PCB concentrations at both stations are similar in 'dissolved' sub-surface and sea-surface microlayer waters while the enrichment found in 'particulate' sea-surface microlayer samples is greater by comparison with the sub-surface water, so it 
can be hypothesised that there must be diffuse sources contributing to PCB contamination of the Venice Lagoon. By contrast, for PAHs it can be observed that sub-surface waters are more contaminated at station 2 than station 1 probably due to intense ship traffic which characterizes the area, while an opposite trend has been observed for sea-surface microlayer waters, probably due to the industrial emissions of Porto Marghera the influence of which would mainly be felt by station 1 . Despite these differences, it has been found that in both stations pollutants are distributed between the two phases in accordance with their molecular weight which reflects their enhanced hydrophobic behaviour. Hydrophobic character of the SML and some processes such as photo-degradation, biological activity may vary considerably the EF both $\mathrm{PAH}$ and PCB.

The analysis of PAH ratios conducted in 'dissolved' and 'particulate' SSW and SML samples confirmed the widely shared hypothesis that hydrocarbon contamination of the Venice Lagoon derived mainly from combustion processes, although the concurrence of other sources such as oil spillage cannot be excluded, especially at station 2 . The most likely source of PCB contamination, on the other hand, may be re-suspension from contaminated sediment followed by strong repartition between the layers in accordance with the chemical properties, as can be hypothesized from the distribution of congeners in the different matrices.

\section{Acknowledgements}

This work was supported by CORILA (Consortium for Coordination of Research Activities concerning the Venice Lagoon System) under the project 'Role of aerosol and secondary pollution in the chemical contamination of the Lagoon of Venice' and by the National Research Council of Italy (CNR).

\section{References}

Abd-Allah, A.M.A., 1999. Organochlorine contaminants in microlayer and subsurface water of Alexandria Coast, Egypt. Journal of AOAC International 82, 391-398.

Anyakora, C., Ogbeche, A., Palmer, P., Coker, H., 2005. Determination of polynuclear aromatic hydrocarbons in marine samples of Siokolo Fishing Settlement. Journal of Chromatography A 1073, 323-330.

Budzinski, H., Jones, I., Bellocq, J., Piérard, C., Garrigues, P., 1997. Evaluation of sediment contamination by polycyclic aromatic hydrocarbons in the Gironde estuary. Marine Chemistry 58, 85-97.

Cincinelli, A., Stortini, A.M., Perugini, M., Cecchini, L., Lepri, L., 2001. Organic pollutants in sea-surface microlayer and aerosol in the coastal environment of Leghorn-(Tyrrhenian Sea). Marine Chemistry 76, 77-98.

Cleary, J.J., Craboledda, L., Campesan, G., 2000. Sea surface microlayer chemistry. In: The Venice Lagoon Ecosystem-Inputs and Interactions Between Land and Sea. In: Jeffers, J.N.R. (Ed.), Man and the Biosphere Series, vol. 25. UNESCO, p. 127.

Cochran, J.K., Frignani, M., Salamanca, M., Bellucci, L.G., Guerzoni, S., 1998. Lead-210 as a tracer of atmospheric input of heavy metals in the northern Venice Lagoon. Marine Chemistry 62, 15-29.

Di Domenico, A., Turrio Baldassarri, L., Ziemaki, G., 1996. Relazione di perizia tecnica sulla qualità e la quantità dell'impatto antropico nella
Laguna di Venezia, vol. 1. Relazione per la Procura della Repubblica presso la Pretura Circondariale, Venezia.

Eljarrat, E., Barceló, D., 2003. Priority lists for persistent organic pollutants and emerging contaminants based on their relative toxic potency in environmental samples. Trends in Analytical Chemistry 22, $655-665$

El Nemr, A., Abd-Allah, A.M.A., 2003. Contamination of polycyclic aromatic hydrocarbons (PAHs) in microlayer and subsurface waters along Alexandria coast, Egypt. Chemosphere 52, 1711-1716.

García-Flor, N., Guitart, C., Bodineau, L., Dachs, J., Bayona, J.M., Albaigés, J., 2005. Comparison of sampling devices for the determination of polychlorinated biphenyls in the sea surface microlayer. Marine Environmental Research 59, 255-275.

Hardy, J.T., Crecelius, E.A., Atrim, L.D., Broadhurst, V.L., Apts, C.W., Gurtisem, J.M., Fortman, T.J., 1987. The sea-surface microlayer of Puget Sound: Part II. Concentrations of contaminants and relation to toxicity. Marine Environmental Research 23, 251-271.

Jones, K.C., de Voogt, P., 1999. Persistent organic pollutants (POPs): state of the science. Environmental Pollution 100, 209-221.

Kucklick, J.R., Bidleman, T.F., 1994. Organic contaminants in Winyah Bay, South Carolina I: pesticides and polycyclic aromatic hydrocarbons in subsurface and microlayer waters. Marine Environmental Research 37, 63-78.

Lerche, D., van de Plassche, E., Schwegler, A., Balk, F., 2002. Selecting chemical substances for the UN-ECE POP Protocol. Chemosphere 47, 617-630.

Liu, K., Dickhut, R.M., 1997. Surface microlayer enrichment of polycyclic aromatic hydrocarbons in Southern Chesapeake Bay. Environmental Science and Technology 31, 2777-2784.

Moret, I., Gambaro, A., Piazza, R., Ferrari, S., Manodori, L., 2005. Determination of polychlorobiphenyl congeners (PCBs) in the surface water of the Venice Lagoon. Marine Pollution Bulletin 50, 167174.

Picer, N., Picer, M., 1992. Inflow, levels and the fate of some persistent chlorinated hydrocarbons in the Rijeka Bay area of the Adriatic Sea. Water Research 26, 899-909.

Sauer, T.C., Durell, G.S., Brown, J.S., Redford, D., Boehm, P.D., 1989. Concentration of chlorinated pesticides and PCBs in microlayer and seawater samples collected in open-ocean waters off the US East Coast and in the Gulf of Mexico. Marine Chemistry 27, 235-257.

Schroeder, W.H., Lane, D.A., 1988. The fate of toxic airborne pollutants. Environmental Science and Technology 22, 240-246.

Secco, T., Pellizzato, F., Sfriso, A., Pavoni, B., 2005. The changing state of contamination in the Lagoon of Venice. Part 1: Organic pollutants. Chemosphere 58, 279-290.

Tam, N.F.Y., Ke, K., Wang, X.H., Wong, Y.S., 2001. Contamination of polycyclic aromatic hydrocarbons in surface sediments of mangrove swamps. Environmental Pollution 114, 255-263.

Tolosa, I., Readman, J.W., Fowler, S.W., Villeneuve, J.P., Dachs, J., Bayona, J.M., Albaigés, J., 1997. PCBs in the western Mediterranean. Temporal trends and mass balance assessment. Deep-Sea Research II 44, 907-928.

Wania, F., Axelman, J., Broman, D., 1998. A review of processed involved in the exchange of persistent organic pollutants across the air-sea interface. Environmental Pollution 102, 3-23.

Wetzel, D.L., Van Vleet, E.S., 2003. Persistence of petroleum hydrocarbon contamination in sediments of the canals in Venice, Italy: 1995 and 1998. Marine Pollution Bulletin 46, 1015-1023.

Wurl, O., Obbard, J.P., 2004. A review of pollutants in the sea-surface microlayer (SML): a unique habitat for marine organisms. Marine Pollution Bulletin 48, 1016-1030.

Zhang, Z., Liu, L., Liu, C., Cai, W., 2003a. Studies on the sea surface microlayer II. The layer of sudden change of physical and chemical properties. Journal of Colloid and Interface Science 264, 148-159.

Zhang, Z.L., Hong, H.S., Zhou, J.L., Huang, J., Yu, G., 2003b. Fate and assessment of persistent organic pollutants in water and sediment from Minjiang River Estuary, Southeast China. Chemosphere 52, 1423 1430 . 